\title{
西日本各地の施設における食道異物症
}

\author{
田辺正博*, 大西 加子*, 金丸 真一* \\ 桐山真 樹*, 勝見 容子**, 藤田修治***
}

\section{Esophageal Foreign Bodies in Western Japan}

\author{
Masahiro Tanabe, M.D.," Kayoko Ohnishi, M.D.," Shinichi Kanemaru, M.D.," \\ Masaki Kiriyama, M.D., ${ }^{*}$ Yoko Katsumi, M.D., ${ }^{* *}$ and Syuji Fujita, M.D. ${ }^{* * *}$ \\ *Department of Otolaryngology, Osaka Red Cross Hospital, Osaka, ${ }^{* *}$ Department of \\ Otolaryngology, Toyosato Hospital, Shiga, and ${ }^{* * *}$ Department of \\ Otolaryngology, Kyoto University Hospital, Kyoto
}

\begin{abstract}
A statistical study was made of cases of esophageal foreign bodies encountered in our clinic during the years from 1979 to 1988 and in selected institutions in western Japan in 1989. The results were as follows.

1) Esophageal foreign bodies were found more often in females than in males in both patient groups. Two peaks were observed in the age distribution; one in children below the age 10 years and the other in the people above 60 years in both patient groups. 2) Coins were the most numerous type of foreign body in the cases at our clinic, while fish bones were prominent in the other area of western Japan. 3) Coins were the most numerous type in children below the age 10 years, whereas PTPs and fish bones were numerous in patients above the age 10 years. 4) Most of the foreign bodies were lodged at the esophageal orifice. 5) Most of the foreign bodies were removed with a rigid esophagoscope. A majority of the cases were treated under general anesthesia. 6) The most common esophageal foreign bodies were PTPs in large cities such as Osaka and Kobe, but fish bones in the other area of western Japan.
\end{abstract}

Key words : esophageal foreign bodies, western Japan, clinical statistics

\section{I .はじめに}

西日本における食道異物症の傾向を検討した。 対象として, 大阪赤十字病院耳鼻咽喉科におけ る1979年から1988年までの10年間の食道異物症 例と西日本各地の施設の耳鼻咽喉科における 1989年 1 年間の食道異物症例を集計し，この 2 群について検討した。集計に御協力頂いた施設

\footnotetext{
*大阪赤十字病院耳鼻咽喉科, **豊郷病院耳鼻咽喉 科, ***京都大学医学部耳鼻咽喉科学教室

別刷請求： 5543 大阪府大阪市天王寺区筆が崎町553 大阪赤十字病院耳鼻咽喉科 田辺正博 投稿受付：1991年 9 月 5 日
}

を表 1 に示す。

\section{II. 集計結果}

\section{1 . 性差, 年齢別頻度}

2 つの群の性別, 年齢層別症例数を図 1 に示 す。大阪赤十字病院で10年間に食道異物を摘出 した症例は142例で，男性66例，女性76例と女性 がやや多い。年齢別には10歳未満の症例が極端 に多く，10歳以上では，年齢が高くなるにした がい症例数が増し, 60歳代, 70歳以上の症例も 多い。

西日本の施設の症例は103例で, 男性41例に対 し女性は62例と約 1.5 倍を占める。10歳末満と 60 
表 1 集計対象施設

\begin{tabular}{ll}
\hline 沖縄赤十字病院 & 奈良医科大学 \\
長崎原爆病院 & 近畿大学 \\
久留米大学 & 大阪医科大学 \\
高知医科大学 & 関西医科大学 \\
松山赤十字病院 & 関西医科大学香里病院 \\
愛媛大学 & 公立豊岡病院 \\
小松島赤十字病院 & 神戸市民病院 \\
山口赤十字病院 & 京都第一赤十字病院 \\
倉敷中央病院 & 京都第二赤十字病院 \\
岡山赤十字病院 & 京都大学 \\
松江赤十字病院 & 大津赤十字病院 \\
和歌山赤十字病院 & 福井赤十字病院 \\
天理よろつ相談所病院 & \\
\hline
\end{tabular}

歳代，70歳以上が多いが，10歳末満の症例数が 大阪赤十字病院の症例ほど極端に多くない。

\section{2. 異物の種類}

異物の種類別頻度を図 2 に示す。図 2 左の大 阪赤十字病院の症例では硬貨が最も多く, 右の 西日本の施設の症例では魚骨が最も多い。PTP 異物症は大阪赤十字病院で $20 \%$, 西日本の施設 で25\%を占め, ともに 2 番目に多い。

異物の種類別の性差を図 3 に示す。硬貨は男 性に多く, 魚骨, PTP は女性に多い。

\section{3 . 年齢と異物の種類}

年齢層別の異物の種類を図 4 に示す。大阪赤 十字病院の症例では10歳未満に極端に大きなピ ークがあり，その $85 \%$ が硬貨異物である。義歯
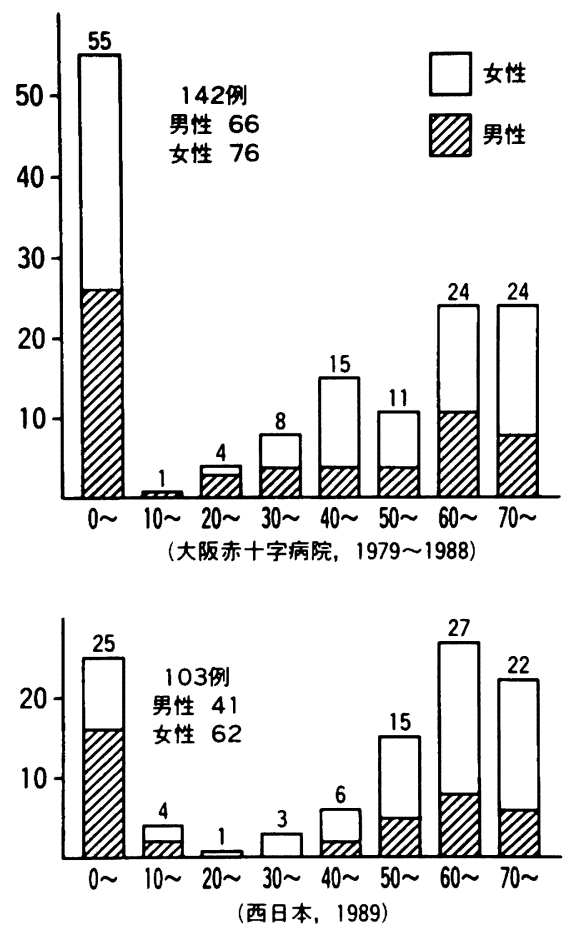

図 1 食道異物症の年㱓分布, 性差

は少なく，魚骨とPTP が広い年齢層に見られ る。その他と表したものには食物塊, 玩具など を含む。西日本の施設の症例でも10歳末満に大 きなピークをもつが, 大阪赤十字病院の症例ほ ど極端ではない。硬貨異物は $64 \%$ と多数を占め るが, 玩具, 魚骨など, その他の異物もかなり 見られる。他の年齢層には魚骨, PTP が多い。

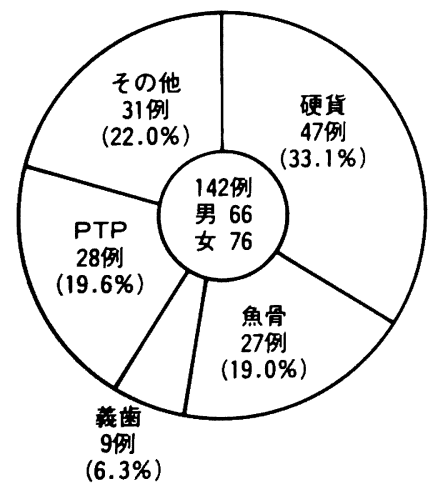

(大阪赤十字病院, 1979 1988)

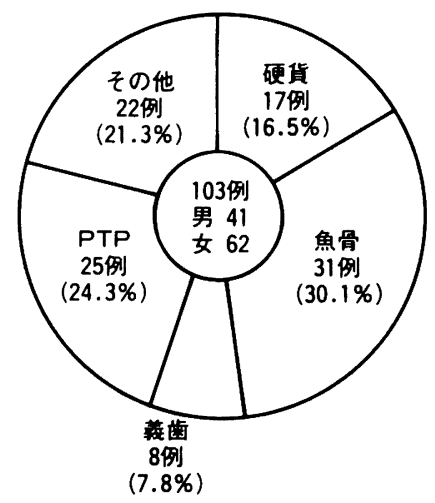

(西日本, 1989)

図 2 食道異物の種類別頻度 

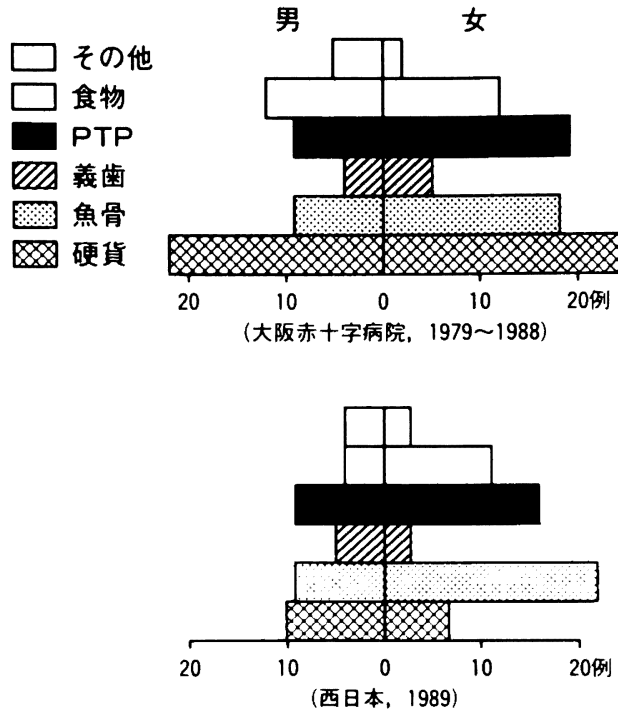

図 3 食道異物の種類別性差

幼小児の食道異物の大部分を占める硬貨の種 類別頻度を表 2 に示す。いずれの集計でも 100 円 硬貨と 10 円硬貨が多い。

成人に多い PTP 異物の年齢層別頻度を表 3 に示す。高齢者のみならず広い年齢層に見られ る。大阪赤十字病院の症例の PTP 異物の内訳を 表 4 に示す。薬剤入りのPTP では確認し得た全 例が錠剂で，カプセルは見られない。図 5 に大 阪赤十字病院の 10 年間の食道異物の年次推移を 示す。年毎に異物の種類は一定しないが, PTP は増加傾向にある。

\section{4 . 異物の嵌在部位}

西日本の施設の症例103例の異物の嵌在部位を 表 5 に示す。第 1 狭窄部が85例と多数を占め, 第 2 狭窄部は 15 例, 第 3 狭窄部は 3 例と少ない。 第 2 狭窄部に嵌在した異物の約半数の 7 例は PTPである。

\section{5. 摘出法と麻酔法}

西日本の施設の103症例の異物摘出法と麻酔 法を表 6 に示す。93例と大部分が硬性鏡下に異 物の摘出を受け，そのうち58例が全身麻酔下， 35例が局所麻酔下の摘出である。異物の種類と 麻酔法の関係を見ると, 硬貨異物と義歯は全身 麻酔下の摘出が多い。PTP と食物塊は局所麻酔 下の摘出がやや多い。軟性ファイバースコープ による摘出は 8 例で，全例局所麻酔下の摘出で
表 2 硬貨の種類別頻度

\begin{tabular}{|c|c|c|}
\hline $\begin{array}{c}\text { 硬貨の種類 } \\
\text { (直径 } \mathrm{mm})\end{array}$ & $\begin{array}{c}\text { 大阪赤十字病院 } \\
(1979 \sim 1988)\end{array}$ & $\begin{array}{c}\text { 西日本 } \\
(1989)\end{array}$ \\
\hline 10 円 $(23.5)$ & 17 & 6 \\
100 円 (22.6) & 21 & 5 \\
5 円 (22.0) & 5 & 2 \\
50 円 (21.0) & 6 & 0 \\
1 円 (20.0) & 0 & 1 \\
不明 & 0 & 2 \\
\hline 計 & 49 & 16 \\
\hline
\end{tabular}

表 3 PTP 異物症の年粭層別頻度 28例 (男 9 例，女19例）（大阪赤十字病院，1979１988）

\begin{tabular}{|c|c|c|c|c|c|c|}
\hline $20 \sim$ & $30 \sim$ & $40 \sim$ & $50 \sim$ & $60 \sim$ & $70 \sim$ & $80 \sim$ \\
\hline 1 & 1 & 2 & 7 & 9 & 5 & 3 \\
\hline
\end{tabular}

25例(男 8 例, 女17例)

(西日本, 1989)

\begin{tabular}{|c|c|c|c|c|c|c|}
\hline $20 \sim$ & $30 \sim$ & $40 \sim$ & $50 \sim$ & $60 \sim$ & $70 \sim$ & $80 \sim$ \\
\hline & 1 & 1 & 4 & 13 & 4 & 2 \\
\hline
\end{tabular}

表 4 PTP の種類

$\begin{array}{lr}\text { PTP 包装のみ } & 9 \text { 例 } \\ \text { PTP 包装十錠剤 } & 13 \text { 例 } \\ \text { PTP 包装十カプセル } & 0 \text { 例 } \\ \text { 不明 } & 6 \text { 例 }\end{array}$

（大阪赤十字病院，1979～1988）

表 5 食道異物の嵌在部位

\begin{tabular}{|l|l|l|}
\hline 第 1 狭窄部 & 85 例 & $\begin{array}{l}\text { 硬貨 } 14, \text { 魚 骨 } 29, \text { 義 歯 } 7, \\
\text { PTP18, 食物塊 } 11, \text { その他 } 6\end{array}$ \\
\hline 第 2 狭窄部 & 15 例 & $\begin{array}{l}\text { 硬貨 } 1, \text { 魚骨 } 2, \text { 義歯 } 1, \text { PTP } \\
7, \text { 食物塊 } 3, \text { その他 } 1\end{array}$ \\
\hline 第 3 狭窄部 & 3 例 & 硬貨 ( 5 円) 2, 食物塊 1 \\
\hline
\end{tabular}

(1989，西日本)

ある。食道外切開は全身麻酔下に 2 例に行われ， いずれも義歯異物である。今回の集計では異物 
日気食会報，43（3）, 1992

表 6 異物の種類と摘出法, 麻酔法

\begin{tabular}{|c|c|c|c|c|c|c|c|}
\hline 摘 出法 & 麻酔 & 硬貨 & 魚骨 & 義歯 & PTP & 食物塊 & その他 \\
\hline 硬 性 鏡 93例 & $\begin{array}{r}\text { 全 } 58 \\
\text { 局 } 35\end{array}$ & $\begin{array}{r}15 \\
5\end{array}$ & $\begin{array}{c}18 \\
11\end{array}$ & $\begin{array}{c}5 \\
1\end{array}$ & $\begin{array}{c}13 \\
5\end{array}$ & $\begin{array}{c}7 \\
1\end{array}$ \\
\hline ファイバー 8 例 & $\begin{aligned} \text { 全 } 0 \\
\text { 局 } 8\end{aligned}$ & & 2 & & 3 & 3 & \\
\hline 外 切 開 2 例 & $\begin{array}{c}\text { 全 2 } \\
\text { 局 } 0\end{array}$ & & & 2 & & & \\
\hline
\end{tabular}
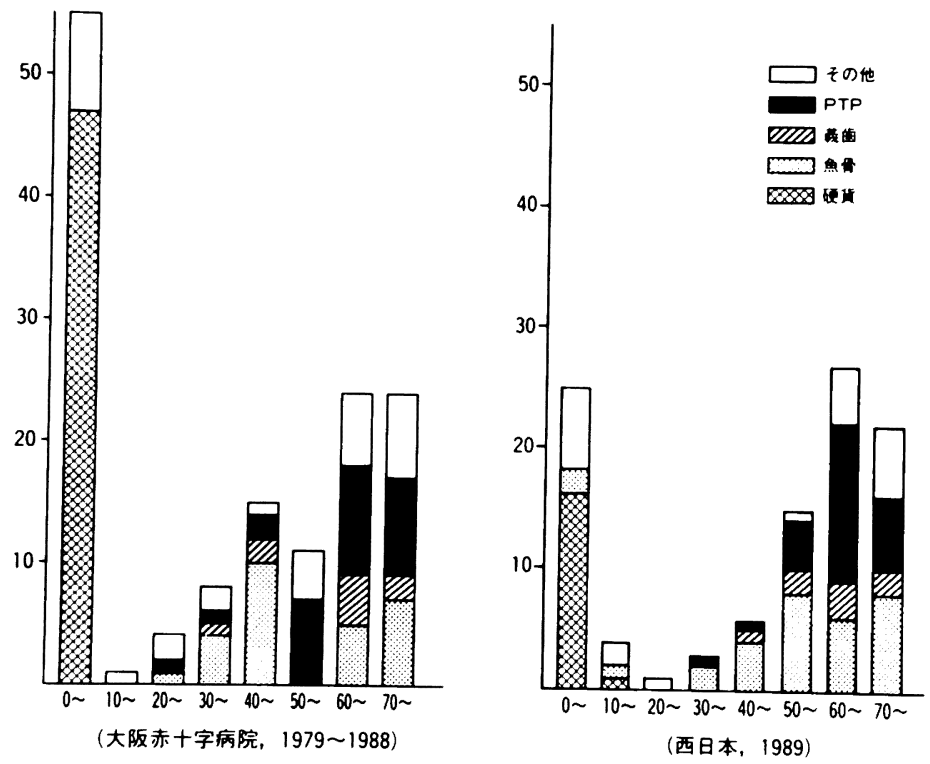

図 4 年齢層別の異物の種類

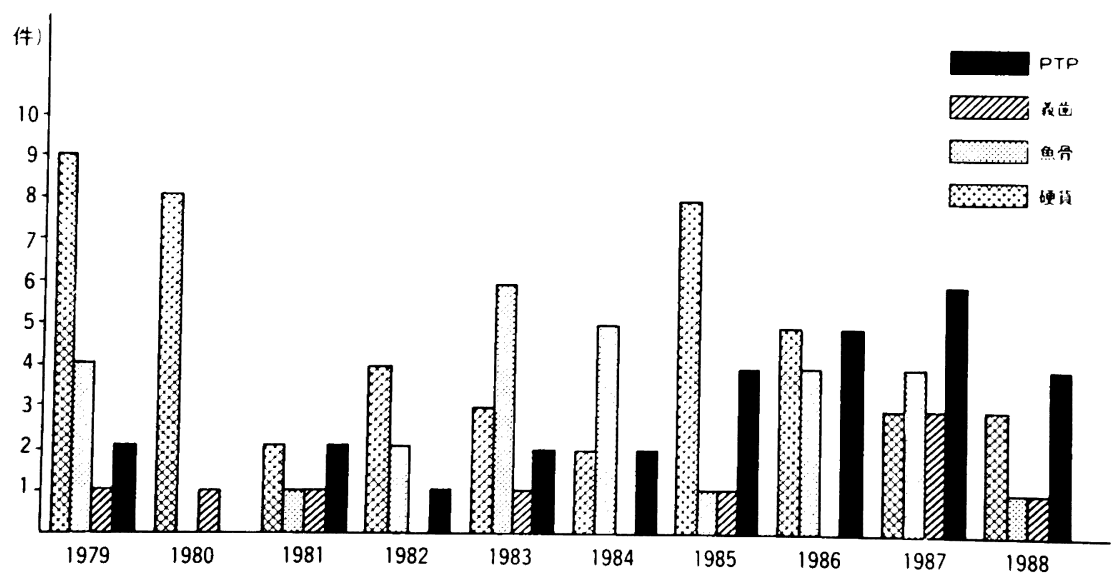

図 5 食道異物の年次推移（大阪赤十字病院） 

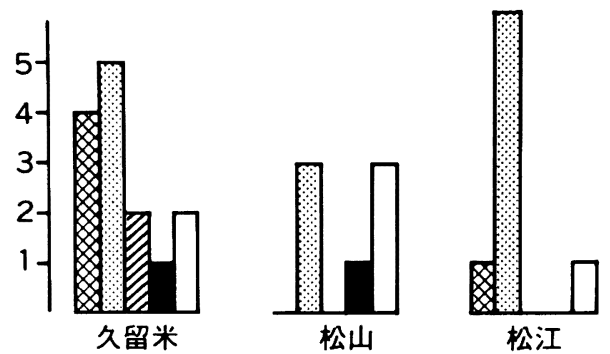

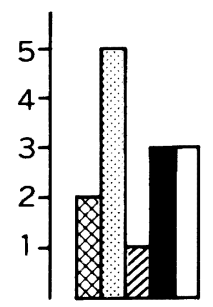

奈良

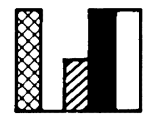

神戸

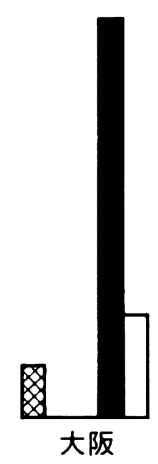

図 6 食道異物の地域差

摘出に伴う重篤な合併症の報告はなかった。

\section{6. 食道異物の地域性}

今回の集計で1989年 1 年間の症例数が多い 6 施設における異物の種類別頻度を図 6 に示す。 魚骨と PTP が多く, 大阪と神戸の施設では PTP が魚骨より多く，その他の地域の施設ではこの 関係が逆転している。

\section{III. 考按}

\section{1. 性差, 年齢別頻度}

年齢別頻度は今回，集計した $2 つ$ 群とも 10 歳末満と60歳以上に 2 つのピークをもち, 諸家 の報告と一致する ${ }^{1-6)}$ 。大阪赤十字病院の集計で は, 西日本の集計に比し10歳未満の症例が極端 に多い。大阪赤十字病院が一次救急も扱ってい るため小児が多いとも考えられるが，最近 1 年 間の集計である西日本の症例で小児の割合が少 ないことから，最近の出生率の低下が小児例減 少の原因とも考えられる。

性差は 2 つ群ともに女性の症例が多かった。 最近の集計で症例数が50例を超える報告をみる と, 性差はないとするものが多く4,5,7,8)男性が多
数を占めるとするもの ${ }^{6)}$, 女性が多いとするもの は少ない。大阪赤十字病院の症例は男性66例, 女性76例とやや女性が多いが，ほとんど性差は ないといえる。最近 1 年間の集計である西日本 の施設の症例では男女比が $2: 3$ と女性が多い。 図 3 に示したごとく，成人例に見られる PTP, 魚骨が女性に多いことが性差に反映している。 最近 1 年間の集計である西日本の症例では硬貨 が少ない（小児例が少ない）こと, 成人例の比 率が高くなっていることで性差は説明できる。 今後も出生率の減少, 高齢化が進めばさらに女 性の比率が高くなるものと考えられる。

\section{2 . 異物の種類}

大阪赤十字病院の症例では硬貨が最多で, 西 日本の施設の症例では魚骨が最も多かったが前 項で論じたごとく, 10 年間の集計と最近 1 年間 の集計における小児例の比率の違いが主な要因 であろう。他の要因として, 図 6 に示した地域 差も関連すると考える。

\section{3 . 年齢と異物の種類}

2 つの群とも10歳未満の症例では硬貨異物が 最多である。10歳未満の全異物に対する硬貨異 物の比率は大阪赤十字病院の症例では $85 \%$ と高 いが，西日本の施設の症例では $64 \%$ とやや低く なっている。また，全症例に対する10歳末満の 症例の比率も西日本の施設の集計では低くなっ ている。これは地域差というより, 前者が10年 間の集計で後者が最近 1 年間の集計であること からくる差であろう。

過去の報告でも，長期間の集計では硬貨異物 が多い。最近 1 年間の集計で硬貨異物が減少し ているのは, 出生率の低下したこととともに, 最近, 幼小児に対して十分な注意が払われるよ うになった結果と思われる。異物となった硬貨 の種類としては，100円硬貨と10円硬貨が多い。 身近にあるためと考えられ, 減少傾向にあると はいえ，より十分な注意が必要である。これら の硬貨の径が食道異物になりやすい大きさであ るとして，硬貨の径を 15 ミリ以下，あるいは 30

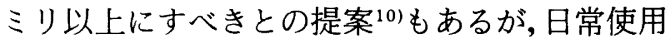
する上での不便もあり現実的ではないと考える。 成人には PTP, 魚骨, 義歯などが広い年齢層 に見られるが, 義歯は過去の報告に比しあまり 多くない。義歯の材質が向上したためと考えて 
いる。図 5 に示したごとく, PTP は近年増加の 傾向にある。投薬量の増加, PTP 包装の増加が この原因と考えられる。PTP は高齢者, 精神障 害者などに多いと考えられがちであるが，林 $ら^{4)}$, 小山ら ${ }^{8)}$ も指摘しているごとく，広い年齢 層に見られ，今回の集計では20歳代の例もあっ た。精神障害者は 1 例もなかった。

PTP は錠剤が多く, 確認し得たものにはカプ セルはなかった。カプセルの方が大きいため異 物になりにくいとも考えられるが，カプセルは 抗生剂, 消炎鎮痛剂に多い剂型で, 急性疾患に 多く用いられ，長期にわたり漫然と服用するこ とが少ないためと考えられる。慢性疾患に用い られる薬羭の多くは錠剤で, 長期にわたり服用 しているために，慣れから，ついうっかり飲ん でしまうということが起こりやすいと考えられ る。PTP の台紙を切り離せないようにすべきと の提案 ${ }^{11}$ はなされているが，まだ実現していな ᄂ。

\section{4. 異物の嵌在部位}

過去の集計 ${ }^{1 \sim 9)}$ と同様, 第一狭窄部に嵌在する ものが圧倒的に多く，第二狭窄部，第三狭窄部 には少なかった。西日本の施設の集計で第二狭 窄部の15例中 7 例が PTP 異物であった。PTP が第一狭窄部のみならず第二狭窄部に多く見ら れる5,6)のは, 薬剤を服用するということで, 積 極的に臙下したためと考えられる

\section{5 . 摘出法と麻酔法}

西日本の施設の症例103例中93例では硬性鏡 下に，8例では軟性ファイバースコープにより 異物が摘出されている。残る 2 例は食道外切開 による摘出である。

ファイバースコープによる異物摘出は, 近年 行われるようになったもので, 長期間の症例を 集計した報告では当然少ない。最近特に耳鼻咽 喉科以外ではファイバースコープによる摘出が 多数を占めるが，今回の集計ではアンケートの 対象を耳鼻咽喉科に限ったため, 硬性鏡下の摘 出が大部分を占めたものと考える。異物の種類 によっては，硬性鏡でなければ安全に摘出でき ないものもあるが，異物の形状によってはファ イバースコープによる摘出も必ずしも危険を伴 うとはいえない。今後はファイバースコープの 使用も増加すると考えられる。
以前は硬性鏡による摘出も殆ど局所麻酔下に 行われていたが，近年，全身麻酔が安全に行え るようになり，施設により多少の差はあるが全 身麻酔下の摘出が多数を占める。硬貨と義歯は 全身麻酔下の摘出が多数を占めたが，硬貨異物 は幼小児に多く，義歯異物は摘出が困難なため と考えられる。

\section{6 . 食道異物の地域性}

西日本の限られた施設の集計ではあるが, PTP 異物と魚骨異物に関しては地域による差が見ら れた。魚骨異物の差は食習慣の違いによるもの との解釈もできるが, PTP 異物の差は投薬量の 違いからくるものであろうか。PTP 異物は医原 性異物であり，投薬する側にも一層の注意が必 要と考える。

\section{IV.まとめ}

大阪赤十字病院における1979年から1988年ま での10年間の食道異物症例と西日本各地の施設 における1989年 1 年間の食道異物症例を集計し た。

1）年齢別頻度は 2 つの群とも 10 歳末満と 60 歳以上にピークを持つ 2 峰性分布を示した。 2 つの群とも女性が多数を占めた。

2 ）大阪赤十字病院の集計では硬貨が，西日 本の施設の集計では魚骨が最多を占めた。

3 ）10歳末満の小児では硬貨異物が多数を占 め,それ以上の年齢層では PTP と魚骨が多く見 られた。

4 ）異物の嵌在部位は第一狭窄部が圧倒的多 数を占めた。

5 ）硬性鏡による摘出が殆どで，麻酔は全身 麻酔が多数を占めた。

6 ）大阪, 神戸では PTP が，その他の地域で は魚骨が多かった。

本論文の要旨は第 42 回日本気管食道科学会学術講 演会（1990年，鹿児島市）において発表した。

\section{文献}

1) 和田好弘, 芹沢泰博, 森 泰雄-他：当教室 7 年間の食道㧍よび気管, 気管支異物の統計的観 察. 日気食会報, $37 ： 262-267,1986$ 。

2 ) 半田 肇, 折田洋造, 山本英一・他：当教室開 
設以来の気道, 食道異物症例の統計. 川崎医学 会誌, $12 ： 349-354,1986$.

3 ) 岡村洋沖, 大梘好正, 大谷 岝：最近 5 年間の 当教室に打ける食道扔よび気道異物症例の統計 的観察.耳鼻臨床, 補10:172-176, 1987.

4 ) 林 光夫, 福田 論, 滝沢昌彦 - 他: 当教室に おける過去10年間の食道異物の統計的観察. 耳 鼻, 34：673-676, 1988.

5 ）小村 良, 佐藤英治, 酒井利忠・他：食道およ び気管・気管支異物の統計的観察－当教室18年 間の集計一。耳鼻臨床，補27：170-182, 1988.

6 ）上田隆志, 衛藤幸男, 柏木令子 - 他：当教室 15 年間の下気道・食道異物の統計的観察。耳鼻臨 床, 補37：223-229, 1990 .
7 ) 樋口彰宏, 鈴木 徹, 斎藤 彰・他：開院以来 10年間の気道食道異物の統計的観察. 日気食会 報, $34 ： 255-259,1983$.

8 ）小山 弘, 大川和春, 岡本康比古 - 他：当院気 管食道科における下気道・食道異物の臨床統計 的観察。日気食会報, $37: 248-256,1986$.

9 ) 石井良介, 小林恵理子, 遠藤悦恵・他：自治医 科大学付属病院における過去 10 年間の気道およ び食道異物の統計的観察. 自治医大紀要, 10 ： 149-156, 1987.

10）調 賢哉：幼児食道貨幣異物の臨床と防止対策. 日気食会報, 25：144-152, 1974 .

11）調 賢哉：PTP 内服薬による食道異物症につい て。日気食会報，26：48-53, 1975 . 